\title{
Cukrinių runkelių produktyvumo optimizavimo tyrimai naudojant bioorganines trąšas
}

\section{Elena Jakienè}

Aleksandro Stulginskio universitetas, Studentu g. 11,

LT-53361 Akademija, Kauno $r$.

El.paštas: elena.jakiene@asu.lt
Lauko bandymai atlikti Aleksandro Stulginskio universiteto (ASU) Bandymų stotyje 2012-2013 m. Tirta papildomo trę̌simo per lapus bioorganinių universaliu nanotrąšų NAGRO įtaka 'Ernestina' veislès cukrinių runkelių (Beta vulgaris L., var. saccharifera) augimui, fotosintetiniams rodikliams, šakniavaisių derlingumui ir kokybei. Prieš sèją bandymų laukas patrę̌stas NPK 8:20:30 $300 \mathrm{~kg} \mathrm{ha}^{-1}+$ amonio salietra $\left(\mathrm{N}_{34}\right) 200 \mathrm{~kg} \mathrm{ha}^{-1}$ (foninis viso bandymo tręšimas - kontrolè). Cukrinių runkelių daigams esant keturių porų tikrųjų lapelių augimo tarpsnyje (17-18 BBCH) augalai apipurkšti bioorganinių universalių nanotrąšu NAGRO 0,5 ir 11 ha $^{-1}$ tirpalais. Antrą kartą bioorganinių trąšu tirpalais cukriniai runkeliai apipurkšti 5-6 porų tikrujjų lapelių augimo tarpsniu (21-22 BBCH). Kitos agrotechninès priemonès buvo atliekamos pagal Bandymų stotyje taikomą cukriniu runkeliu auginimo technologiją. Cukriniu runkeliu derlius nuimtas spalio 3 d. Šakniavaisių cukringumas nustatytas Marijampolès cukraus fabrike šaltosios digestijos metodu.

Gauti bandymo rezultatai parodè, kad didesnę itaką cukrinių runkelių augimui ir produktyvumui darẻ augalų apipurškimas du kartus bioorganinių nanotrą̧̌u NAGRO $11 \mathrm{ha}^{-1}$ tirpalais. Taip apipurškus, cukriniai runkeliai intensyviau augo ir kaupe sausas medžiagas, grynasis fotosintezės produktyvumas padidèjo $18,4 \%$, palyginti su tirtomis bioorganinėmis trą̌somis neapipurkštais augalais.

Cukrinių runkelių daigus apipurškus bioorganinių nanotrąšų NAGRO 11 ha $^{-1}$ tirpalu du kartus, šakniavaisių derlingumas patikimai padidèjo $9,29 \mathrm{t} \mathrm{ha}^{-1}$, cukringumas - $1,14 \%$, baltojo cukraus gauta $1,90 \mathrm{t} \mathrm{ha}^{-1}(22,9 \%)$ daugiau, palyginti su kontroliniuose bandymo laukeliuose augusiais cukriniais runkeliais.

Raktažodžiai: cukriniai runkeliai, bioorganinės trąšos, fotosintetiniai rodikliai, derlingumas, cukringumas

\section{IVADAS}

Norint optimizuoti lauko augalų produktyvumą reikia sukurti optimalias jų augimo sąlygas, kurios kiek galima paspartintų gyvybinius procesus, vykstančius augaluose, ir turètų ittakos augalų produktyvumui. Tačiau sumažèjusios gyvulininkystès apimtys lèmè, kad tik labai maža dalis žemès ūkio naudmenų tręšiama mèšlu, javai pasèlių struktūroje sudaro didesnę negu optimalią dalị, o daugiamečių žoliu, kurios yra svarbus humuso šaltinis, dalis pasèlių struktūroje labai sumažèjo. Minèti pasèlių struktūros pokyčiai turi neigiamos itakos dirvožemio agrocheminèms, fizikinèms ir biologinėms savybėms (Mažvila ir kt., 2003). Dirvožemis yra namai milijardams mikroorganizmų, vykdančių biocheminès transformacijos ciklą, prasidedanti atmosferinio azoto fiksacija ir besibaigiantị organinès medžiagos suardymu, - taip sukuriamos tinkamos sąlygos augalams augti ir pasisavinti maisto medžiagas iš dirvos. Tačiau net ir tinkamai parinkus pagrindinius lauko augalų auginimo agrotechnikos elementus, augalus neišvengiamai veikia ir negatyvūs augimo veiksniai, sukeliantys jiems stresą (Deveikytè, 2000). Taigi lauko augalų produktyvumas tiesiogiai priklauso ir nuo to, kaip greitai jie geba prisitaikyti prie nepalankių augimui sąlygų ir kaip greitai gali 
atsigauti pasibaigus šių sąlygų veikimui. Dažniausiai augalai atsigauna, bet ju gyvybinès funkcijos susilpnejja - sutrinka fotosintezè ir maisto medžiagų apykaita (Narkevičius ir kt., 2004; Jakienė, 2013; Mickevičius ir kt., 2013).

Žemès ūkio augalų produktyvumą žemdirbiai dažniausiai stengiasi padidinti gausiau tręšdami azoto trąšomis ir sunaudodami nepagrịstai daug augalų apsaugos priemonių. Daugelis ūkininkų per daug naudoja mineralinių trąšų ir neteikia reikiamo dèmesio organinių trąšų itterpimui ar humuso atstatymui dirvoje kitomis priemonemis. Dèl to dirvos struktūra blogeja, mažeja humuso kiekis, augalai pradeda jausti deguonies badą, mažèja lauko augalų produktyvumas (Šlapakauskas ir kt., 2008). Be to, kad išliktų tolygiai aukštas derlingumas, reikia vis daugiau mineraliniu trąšų. Intensyviai tręšiant ir gausiai naudojant augalų apsaugos priemones pablogèja dirvožemio būklè, nes naikinant patogenus sunaikinamos ir regeneratyvinès dirvos bakterijos. Suardžius normalią dirvos mikrobiologinę struktūrą, pradeda dominuoti patogeniniai mikroorganizmai, slopindami „geruosius" probiotinius mikroorganizmus. Ilgainiui dirvožemis pradeda degraduoti (Šiuliauskas ir kt., 2008). Pastebèta, kad net ịterpus ị dirvą organikos, joje nevyksta iprastiniai humufikavimo procesai (Pidgeon et al., 2006; Šiuliauskas, Liakas, 2012).

Ilgą laiką žemès ūkio produktų gamybos technologijose nebuvo skiriama pakankamai demesio biologiniams dirvos procesams ir juos lemiantiems dėsniams. Biologinių dèsnių pažeidimai neigiamai veikia dirvožemio gyvybès formas, mažina jų aktyvumą ir dirvožemio natūralų derlingumą (Deveikytė ir kt., 2009). Biologiškai neaktyviose dirvose sumažèja natūralus augalų atsparumas ligoms ir kenkèjams. Iš tokių dirvožemių gaunami mažesnę maistinę vertę turintys augaliniai produktai (Pranckietiené ir kt., 2008). Pesticidų naudojimas naikinant kultūriniams augalams žalingus vabzdžius, augalų ligas bei piktžoles, neišvengiamai užteršia produkciją, kelia pavojų žmonių ir gyvūnų sveikatai, visai gyvajai aplinkai (Mažvila ir kt., 2008). Todèl šiandien, norint atstatyti dirvos mikroflorą, naudojami mikrobiologiniai preparatai, sudaryti iš iqvairių probiotinių mikroorganizmų, atstatančių mikrobiologinę dirvos struktūrą ir taip optimizuojantys kultūrinių augalų augimo sąlygas (Suojala, 2000; Shpaar, 2006; Romaneckas ir kt., 2009).
Didžiausias efektas gaunamas kartu naudojant organines ir mikrobiologines trąšas, taip vyksta ir gamtoje. Tokiu būdu sukuriamos optimalios augalų maitinimosi sąlygos, išsaugoma dirvos struktūra bei humuso sluoksnio susidarymas (Mažvila ir kt., 2003).

Šiuolaikinių inovatyvių augalų auginimo technologijų pagrindas - sujungti $\mathfrak{i}$ vieningą sistemą ịvairius dirvožemio, agrotechnikos bei augalų savybių parametrus. Manoma, kad naudojant mikrobiologinius preparatus ar bioorganines trąšas galima padidinti mineralinių trąšų efektyvumą, optimizuoti augalų mitybą, pagerinti dirvožemio struktūrą ir sumažinti energijos, skirtos žemès dirbimui, išlaidas, tokiu būdu sumažinant žemès ūkio technikos išmetamųjų dujų kiekị, produkcijos savikainą ir padidinant produkcijos konkurencingumą rinkoje (Jakienè ir kt., 2008).

Tyrimų tikslas - papildomai augalus tręšiant per lapus nustatyti bioorganinių nanotrąšų NAGRO įtaką cukrinių runkelių augimui, fotosintetiniams rodikliams ir produktyvumui.

\section{TYRIMŲ METODAI IR SĄLYGOS}

Tikslieji laiko bandymai atlikti $2012-2013$ m. ASU Bandymų stotyje, karbonatingame sekliai glejišskame išplautžemyje (Calc(ar)i-Epihypogleyic Luvisols), IDg8-k ( $L V g-p-w-c c)$. Dirvožemis neutralios arba silpnai šarminès reakcijos - $\mathrm{pH} 7,2$, hidrolizinis rūgštumas - 1,80 mekv. $100 \mathrm{~g}^{-1}$, sorbuotų bazių suma - 19,0 mekv. $100 \mathrm{~g}^{-1}$, bendrojo azoto $0,155 \%$, judriojo fosforo $\left(\mathrm{P}_{2} \mathrm{O}_{5}\right)-238-250 \mathrm{mg} \mathrm{kg}^{-1}$, judriojo kalio $\left(\mathrm{K}_{2} \mathrm{O}\right)$ - 154-172 $\mathrm{mg} \mathrm{kg}^{-1}$, humuso - 1,70$2,45 \%$. Dirvožemio analizès atliktos Lietuvos agrarinių ir miškų mokslų centro filialo Agrocheminių tyrimų laboratorijoje, Analitiniame skyriuje. Tyrimo metodai: $\mathrm{pH} \mathrm{mol} / \mathrm{l} \mathrm{KCl}$ suspensijoje; judriojo fosforo $\left(\mathrm{P}_{2} \mathrm{O}_{5}\right)$ ir judriojo kalio $\left(\mathrm{K}_{2} \mathrm{O}\right)$ koncentracija, Egnerio-Rimo-Domingo (A-L) metodas.

Grynasis fotosintezès produktyvumas apskaičiuotas pagal formulę:

$$
F_{p r}=M_{2}-M_{1} / 1 / 2\left(L_{0}+L_{1}\right) \cdot T \text {, }
$$

kur $F_{p r}$ - fotosintezès produktyvumas $\left(\mathrm{g} \mathrm{cm}^{-2}\right.$ per parą); $M_{2}-M_{1}$ - sausos masés prieaugis per tam tikrą laikotarpi $(\mathrm{g}) ; L_{0}$ ir $L_{1}$ - lapų plotas laikotarpio pradžioje ir pabaigoje $\left(\mathrm{cm}^{2}\right) ; T$ - laikotarpio trukmè paromis. 
Baltojo cukraus kiekis $\left(\mathrm{t} \mathrm{ha}^{-1}\right)$ apskaičiuojamas pagal formulę:

$$
C k=D \times A / 100,
$$

kur $A$ - cukraus išeiga, nustatoma pagal formulę:

$$
A=B-0,9-C,
$$

čia 0,9 - cukraus nuostoliai iki melasos,

C - cukraus nuostoliai melasoje (koef. 3,38).

Lauko bandymai atlikti pagal schemą:

1. Kontrolè (NPK 8:20:30 $300 \mathrm{~kg} \mathrm{ha}^{-1}+$ amonio salietra $\left(\mathrm{N}_{34}\right) 200 \mathrm{~kg} \mathrm{ha}^{-1}$ - foninis viso bandymo tręšimas).

2. Daigai apipurkšti NAGRO 0,51 ha $^{-1} 1$ kartą (17-18 BBCH).

3. Daigai apipurkšti NAGRO 11 ha $^{-1} 1$ kartą (17-18 BBCH).

4. Daigai apipurkšti NAGRO $0,51 \mathrm{ha}^{-1} 2$ kartus (17-18 ir 21-22 BBCH).

5. Daigai apipurkšti NAGRO $11 \mathrm{ha}^{-1} 2$ kartus (17-18 ir 21-22 BBCH).

Variantai pakartojimų blokuose išdèstyti rendomizuotai, keturiais pakartojimais. Pradinio laukelio plotas - 12,6 $\mathrm{m}^{2}$, apskaitomojo laukelio plotas $-9,0 \mathrm{~m}^{2}$. Gautų duomenų patikimumas apskaičiuotas statistinès analizés metodu naudojant statistinę duomenų ịvertinimo kompiuterinę programą ANOVA iš paketo SELEKCIJA (Tarakanovas ir kt., 2003).

Agrotechninės priemonès. Cukrinių runkelių priešsèlis - žieminiai kviečiai. Pavasarị, pradejjus įdirbti pradžiūvusią dirvą, atliktas foninis bandymo tręšimas - išbertos kompleksinès NPK 8:20:30 $300 \mathrm{~kg} \mathrm{ha}^{-1}$ trąšos. Prieš sejją išpurkštas dirvinis herbicidas Pyramin Turbo 5,0 $1 \mathrm{ha}^{-1}$. Dirva prieš sejją įdirbta germinatoriumi ir balandžio 24 d. pasèti 'Ernestina' veislès cukriniai runkeliai, tankis - 6-7 dražuotos sèklos eilutès išilginiame metre, tarpueiliai - $45 \mathrm{~cm}$ pločio. Gegužès pradžioje, atsinaujinus piktžolių dygimui, laukas nupurkštas herbicidu Betanal Expert 1,30 1 ha $^{-1}$. Cukrinių runkelių bandymų laukas papildomai patręštas amonio salietra $\left(\mathrm{N}_{34}\right) 200 \mathrm{~kg} \mathrm{ha}^{-1}$. Cukrinių runkelių daigams esant keturių porų tikrųjų lapelių augimo tarpsnyje (17-18 augimo tarpsnis pagal BBCH skalę) augalai pagal schemą apipurkšti bioorganinių universalių nanotrąšų NAGRO tirpalais. Piktžolès naikintos panaudojus herbicidų Betanal Expert 1,1 l /ha + Lontrel 0,30 1 ha $^{-1} \mathrm{mi}^{-}$ šinị. Antrą kartą bioorganinių trąšų tirpalais pagal bandymų schemą cukriniai runkeliai apipurkšti 5-6 porų tikrųjų lapelių augimo tarpsniu (21-22 augimo tarpsnis pagal $\mathrm{BBCH}$ skalę). Cukrinių runkelių derlius nuimtas rankiniu būdu naudojant traktorini šakniavaisių keltuvą. Runkelių derlingumas nustatytas pasvèrus apskaitiniame laukelyje užaugusius šakniavaisius ir perskaičiavus it $\mathrm{t} \mathrm{ha}^{-1}$. Sveriant suskaičiuoti laukelyje augę šakniavaisiai ir nustatytas augalų skaičius hektare. Nuimant derlių iš kiekvieno bandymų laukelio paimti šakniavaisių pavyzdžiai (po 25 šaknis) cukringumui nustatyti. Šakniavaisių cukringumas nustatytas Marijampolès cukraus fabrike šaltosios digestijos metodu.

NAGRO - tai skysta koncentruota bioorganiné trąša, kurią gaminant naudojamos mikrobiologinès technologijos, pagrịstos ne cheminiu, bet išskirtinai fiziniu poveikiu. Tokios trąšos sukelia bendro veikimo efektą (sinergizmą), kai atskiru sudedamųjų dalių poveikis augalui viršija jų veikimą atskirai. I trąšų sudèti ịeina: mikrohumatai su prijungtais mikroelementais ( $\mathrm{Mn}, \mathrm{Mo}, \mathrm{Zn}, \mathrm{Co}$, $\mathrm{Fe}, \mathrm{B}$ ir kt.), natūralios kilmès biologiškai aktyvios medžiagos ir naudinga mikroflora. Augalus apipurškus šiomis trąšomis, stimuliuojami biocheminiai procesai, augalo ląstelès išeikvoja mažiau energijos, reikalingos naudingoms medžiagoms prasiskverbti pro membraną. Augalus apipurškus šių trąšu tirpalu, padidejja atsparumas nepalankioms augimui sąlygoms, intensyviau vyksta fotosintezès procesai. Naudojant su mineralinèmis trąšomis augalai lengviau pasisavina trąšose esančias maisto medžiagas, gaunamas didesnis ir geresnès kokybès derlius.

Meteorologinès sąlygos. $2012 \mathrm{~m}$. pavasaris buvo ankstyvas ir šiltas. Cukriniai runkeliai pasèti balandžio 24 d. Ši mènesị meteorologinès sąlygos sejjai ir sèklų dygimui nebuvo labai palankios. Nors vidutinè paros temperatūra buvo aukštesnè už daugiametị vidurkį, trūko drègmès dygti sékloms bei augti daigams.

Gegužès mèn. vyravo vidutiniškai šilti orai. Didžiausias kritulių kiekis iškrito antrąją dekadą - $22 \mathrm{~mm}$., tačiau mènesio kritulių kiekis mažai skyrèsi nuo daugiamečio vidurkio - 47,0 mm. Daigų augimui sąlygos buvo optimalios.

Birželio mèn. buvo šiltas. Aukščiausia oro temperatūra fiksuota mènesio pradžioje, kai vidutine paros temperatūra siekè $21,2^{\circ} \mathrm{C}$. Mènesio vidutinè temperatūra buvo $2,6^{\circ} \mathrm{C}$ aukštesnè už daugiameti vidurki. 
Liepos mèn. buvo šilčiausias iš vasaros mènesių. Šilčiausios - antroji ir trečioji mènesio dekados, o vidutinè paros temperatūra siekè $19,6{ }^{\circ} \mathrm{C}$. Dèl gausių kritulių dirvos buvo šlapios, per mènesi iškrito $146 \mathrm{~mm}$. kritulių. Cukrinių runkelių augimo ir derliaus formavimosi metu meteorologinès sąlygos nebuvo palankios.

Rugpjūčio mèn. gausiai lijo. Per mènesį iškrito net $152,0 \mathrm{~mm}$ kritulių, t. y. $82,2 \mathrm{~mm}$. daugiau už daugiameti vidurkị. Vidutinè ménesio temperatūra buvo $0,8{ }^{\circ} \mathrm{C}$ aukštesnè už daugiametị vidurkị. Nuimant cukrinių runkelių derlių dirvos buvo i̇mirkusios. Cukriniai runkeliai nukasti spalio $3 \mathrm{~d}$.

2013 m. balandžio antrąją ir trečiąją dekadomis kritulių iškrito nedaug, vidutinè paros temperatūra buvo artima daugiametei. Cukrinių runkelių sejjos ir sèklų dygimo metu sąlygos buvo palankios. Gegužès-birželio mèn. palijo gausiau, vidutinè paros temperatūra buvo $3-4{ }^{\circ} \mathrm{C}$ aukštesnè už daugiametę. Cukrinių runkelių augimui sąlygos buvo palankios. Liepos mèn. gausiai lijo, krituliu iškrito $35 \mathrm{~mm}$ daugiau už daugiametị vidurkị, tačiau cukriniai runkeliai jau buvo suformavę šaknų sistemą ir lapų paviršius dengè tarpueilius, todèl žymesnès neigiamos ịtakos gausūs krituliai jų augimui neturejo. Rugpjūčio mèn. kritulių kiekis ir vidutiné paros temperatūra buvo artimi daugiamečiams vidurkiams. Gausesni krituliai iškrito rugsejjo antrąją dekadą, o rugsèjo trečiąją ir spalio pirmają dekadomis kritulių iškrito nedaug, taigi dirva buvo vidutiniškai drègna, sąlygos nuimti cukrinių runkelių derlių buvo palankios.

\section{TYRIMŲ REZULTATAI IR JŲ APTARIMAS}

Cukrinių runkelių apipurškimas bandyme tirtais bioorganinių trąšų tirpalais teigiamai veikè runkelių augimo ir vystymosi procesus. 23-24 augimo tarpsniu (pagal $\mathrm{BBCH}$ skalę) atlikti biometriniai matavimai parodė, kad cukrinių runkelių lapų augimą labiau skatino tręšimas didesnès koncentracijos $\left(1 \mathrm{~L} \mathrm{ha}^{-1}\right)$ trąšų tirpalais. Patręšti vieną kartą daigai išaugino vidutiniškai 3,7 lapais (18,7 \%) patikimai daugiau, nei papildomai netręšti augalai. Cukrinių runkelių daigus vieną kartą apipurškus 0,5 $\mathrm{L} \mathrm{ha}^{-1}$ bioorganinių nanotrąšų NAGRO tirpalu, augalai išaugino vidutiniškai 0,8 (4\%) lapais daugiau, nei papildomai netręšti daigai, tačiau šis skirtumas nèra esminis (1 lentelè).
Geresni rezultatai gauti cukrinius runkelius bioorganinių nanotrąšų NAGRO tirpalais apipurškus du kartus. Taip apipurškus NAGRO trąšų $0,5 \mathrm{~L} \mathrm{ha}^{-1}$ tirpalais runkeliai išaugino vidutiniškai 2,5 (12,6 \%) lapų patikimai daugiau, o du kartus apipurškus $1 \mathrm{~L} \mathrm{ha}^{-1}$ tiriamų trąšų tirpalais - vidutiniškai 4,6 (23,2 \%) lapais patikimai daugiau, palyginti su kontroliniuose bandymo laukeliuose augusiais cukriniais runkeliais.

Biometrinius matavimus pakartojus runkelių lapams susilietus eilutèse (26-27 $\mathrm{BBCH})$, nustatyta, kad intensyviau runkelių lapai augo taip pat tuose bandymo laukeliuose, kur apipurškimui panaudotas didesnès koncentracijos $\left(1 \mathrm{~L} \mathrm{ha}^{-1}\right)$ tirtų trąšu tirpalas. Taip patręšus cukrinius runkelius vieną kartą, augalai išaugino vidutiniškai 4,8 (17,4 \%) lapais daugiau, nei kontroliniuose bandymo laukeliuose auge cukriniai runkeliai. Du kartus apipurkšti $1 \mathrm{~L} \mathrm{ha}^{-1}$ bioorganinių nanotrąšu NAGRO tirpalais cukriniai runkeliai 26-27 augimo tarpsniu buvo išauginę vidutiniškai 7,6 (27,6 \%) lapu daugiau, palyginti su šiomis trąšomis netręštais cukriniais runkeliais.

Šakniavaisių augimą taip pat labiau skatino cukrinių runkelių du kartus apipurškimas bioorganinių nanotrąšų NAGRO tirpalais. Tręšimui per lapus vieną kartą panaudojus $1 \mathrm{~L} \mathrm{ha}^{-1}$ šių trąšu tirpalą, vidutinis šakniavaisių diametras 23-24 $\mathrm{BBCH}$ cukrinių runkelių augimo tarpsniu patikimai padidejo $1,1 \mathrm{~cm}(11,9 \%)$, o du kartus augalus apipurškus $1 \mathrm{~L} \mathrm{ha}^{-1}$ NAGRO trąšu tirpalu, vidutinis šakniavaisių diametras buvo $1,5 \mathrm{~cm}(16,3 \%)$ patikimai didesnis, nei kontroliniuose bandymo laukeliuose augusių cukrinių runkelių.

Biometrinius šakniavaisių matavimus pakartojus 23-27 (BBCH) augimo tarpsniu, apipurkšti NAGRO trąšų tirpalais cukrinių runkelių šakniavaisiai buvo stambesni. Runkelius tiriamų trąšų tirpalais apipurškus vieną kartą, nustatytas 1,0$1,4 \mathrm{~cm}(8,5-11,9 \%)$ didesnis šakniavaisių diametras, o trąšu NAGRO tirpalais cukrinius runkelius apipurškus du kartus, šakniavaisių diametras patikimai padidejo $1,3-1,9 \mathrm{~cm}(11,1-16,2 \%)$, palyginti su kontroliniuose bandymo laukeliuose augusiais cukriniais runkeliais (1 lentelè).

Daugiau biomasès cukriniai runkeliai užaugino papildomai per lapus patręšti bioorganiniu universalių nanotrąšų NAGRO $1 \mathrm{~L} \mathrm{ha}^{-1}$ tirpalu. Taip patręšus vieną kartą, vidutinè augalo biomasè patikimai padidèjo 69,8 g (10,4\%), palyginti su 
1 lentelè. Papildomo tręšimo per lapus bioorganinès universalios nanotrąšos NAGRO tirpalais ịtaka cukrinių runkelių augimui

Table 1. Effect of the additional leaf spray fertilization with the universal NAGRO nano fertilizer solution on sugar beet

\begin{tabular}{|c|c|c|c|c|c|c|c|c|c|}
\hline \multirow{3}{*}{$\begin{array}{c}\text { Bandymo variantai } \\
\text { Trail variants }\end{array}$} & \multicolumn{3}{|c|}{$\begin{array}{l}\text { Lapų skaičius } \\
\text { Leaf number }\end{array}$} & \multicolumn{3}{|c|}{$\begin{array}{c}\text { Šakniavaisio } \\
\text { diametras } \\
\text { Root diameter }\end{array}$} & \multicolumn{3}{|c|}{$\begin{array}{l}\text { Vidutinè augalo biomase } \\
\text { Average plant biomass }\end{array}$} \\
\hline & \multirow[t]{2}{*}{$\begin{array}{l}\text { vnt. } \\
\text { Unit }\end{array}$} & \multicolumn{2}{|c|}{ 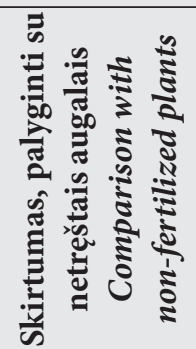 } & \multirow[t]{2}{*}{$\mathrm{cm}$} & \multicolumn{2}{|c|}{ 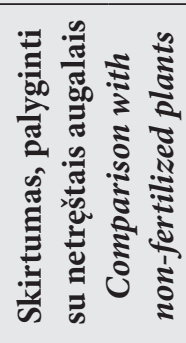 } & \multirow[t]{2}{*}{ g } & \multicolumn{2}{|c|}{ 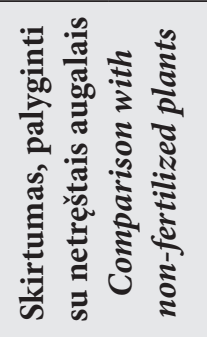 } \\
\hline & & $\begin{array}{l}\text { vnt. } \\
\text { Unit }\end{array}$ & $\%$ & & $\mathrm{~cm}$ & $\%$ & & $\mathbf{g}$ & $\%$ \\
\hline
\end{tabular}

23-24 augimo tarpsnis $(\mathrm{BBCH}) / 23-24$ growth stage $(\mathrm{BBCH})$

1. Kontrolinis variantas (foninis NPK tręšimas)

Control variant (background appli-

19,8

9,2

672,8 cation of NPK)

2. Daigai apipurkšti NAGRO

$0,5 \mathrm{~L} \mathrm{ha}^{-1} 1$ kartą

Single application of NAGRO $0.5 \mathrm{l} \mathrm{ha}{ }^{-1}$

20,6

on the shoots

3. Daigai apipurkšti NAGRO $1 \mathrm{~L} \mathrm{ha}^{-1}$ 1 kartą

Single application of NAGRO $1.0 \mathrm{l} \mathrm{ha}^{-1}$

$23,5 \quad+3,7 \quad 18,7 \quad 10,3 \quad+1,1$

$11,9 \quad 742,6 \quad+69,8$

10,4

on the shoots

4. Daigai apipurkšti NAGRO

$0,5 \mathrm{~L} \mathrm{ha}^{-1} 2$ kartus

Double application of NAGRO

$22,3 \quad+2,5 \quad 12,6 \quad 10,0 \quad+0,8$

$8,7 \quad 725,1 \quad+52,3$

7,7

$0.5 \mathrm{lha}^{-1}$ on the shoots

5. Daigai apipurkšti NAGRO $1 \mathrm{~L} \mathrm{ha}^{-1}$

2 kartus

Double application of NAGRO

$24,4+4,6$

23,2

$10,7+1,5$

16,3

759,0

12,8

$1.0 \mathrm{lha}^{-1}$ on the shoots

\begin{tabular}{ccc}
\hline$L S D_{05}$ & 1,13 & 0,50 \\
\hline & $26-27$ augimo tarpsnis $(\mathrm{BBCH}) / 26-27$ growth stage $(\mathrm{BBCH})$ \\
\hline
\end{tabular}

1. Kontrolinis variantas (foninis NPK tręšimas)

Control variant (background appli-

27,5

11,7

1138,8 cation of NPK)

2. Daigai apipurkšti NAGRO

$0,5 \mathrm{~L} \mathrm{ha}^{-1} 1$ kartą

Single application of NAGRO $0.5 \mathrm{lha}^{-1}$

$29,7 \quad+2,2 \quad 8,0$

12,7

$+1,0$

8,5

1290,3

13,3

on the shoots

3. Daigai apipurkšti NAGRO $1 \mathrm{~L} \mathrm{ha}^{-1}$

$$
1 \text { kartą }
$$

Single application of NAGRO $1.0 \mathrm{l} \mathrm{ha-1}$

$32,3+4,8$

$17,4 \quad 13,1$

$+1,4$

$11,9 \quad 1429,2 \quad+290,4$

25,5

on the shoots 
1 lentelè (tęsinys)

Table 1 (continued)

4. Daigai apipurkšti NAGRO

$0,5 \mathrm{~L} \mathrm{ha}^{-1} 2$ kartus

Double application of NAGRO

32,9

$+5,4$

19,6

13,0

$+1,3$

$11,1 \quad 1449,3 \quad+310,5$

27,1

$0.5 \mathrm{lha}^{-1}$ on the shoots

5. Daigai apipurkšti NAGRO $1 \mathrm{~L} \mathrm{ha}^{-1}$

2 kartus

Double application of NAGRO

$35,1 \quad+7,6 \quad 27,6 \quad 13,6 \quad+1,9$

$16,2 \quad 1615,1+476,3$

41,6

$1.0 \mathrm{lha}^{-1}$ on the shoots

\begin{tabular}{rrrr}
\hline LSD $_{05}$ & 1,58 & 0,62 & 70,39 \\
\hline
\end{tabular}

Šaltiniai: ASU Bandymų stotis, 20012-2013 m. vidutiniai duomenys.

Sources: ASU Experimental Station, mean data for the 2012-2013 period.

papildomai netręštais augalais. Runkelius papildomai per lapus du kartus patręšus tiriamų trąšų tirpalu, vidutinè augalo biomase, palyginti su papildomai netręštais augalais, patikimai padidejo 86,2 g $(12,8 \%)$.

Tyrimus pakartojus cukriniams runkeliams esant 26-27 (BBCH) augimo tarpsnyje, daugiau biomasès buvo išauginę papildomai per lapus patręšti augalai. Cukrinius runkelius bioorganinių nanotrąšu NAGRO tirpalais apipurškus vieną kartą, vidutinè augalo biomasè patikimai padidèjo $151,5-290,4 \mathrm{~g}(13,3-25,5 \%)$, o apipurškus du kartus - 310,5-476,3 g (27,1-41,6\%), palyginti su NAGRO trąšų tirpalais neapipurkštų cukrinių runkeliu vidutine augalo biomase.

Praejjus 14 dienų po apipurškimo NAGRO trąšų tirpalais, nustatytas ir didesnis cukrinių runkelių lapų plotas. Augalus apipurškus vieną kartą, didesnis asimiliacinis lapu plotas nustatytas panaudojus didesnès koncentracijos ( $\left.1 \mathrm{~L} \mathrm{ha}^{-1}\right)$ tiriamų trąšuc tirpalą. Taip apipurškus, cukrinių runkelių lapų plotas patikimai padidejo $317,13 \mathrm{~cm}^{2}(9,15 \%)$, palyginti su kontroliniuose bandymo laukeliuose augusių runkelių lapų plotu (2 lentelè). Cukrinius runkelius vieną kartą apipurškus $0,5 \mathrm{~L} \mathrm{ha}^{-1}$ bioorganinių nanotrąšu NAGRO tirpalu, asimiliacinis lapų plotas patikimai padidejo $292 \mathrm{~cm}^{2}$ $(7,72 \%)$, palyginti su trąšu tirpalu neapipurkštais augalais. Cukrinius runkelius pagal bandymų schemą NAGRO trąšų tirpalais apipurškus du kartus, asimiliacinis lapų plotas patikimai padidèjo $463,83-519,89 \mathrm{~cm}^{2}(12,22-13,70 \%)$, palyginti su kontroliniuose bandymo laukeliuose augusių cukrinių runkelių lapų plotu.

Lapų ploto matavimus pakartojus po 3 savaičių lapų susilietimo eilutèse augimo tarpsniu
(26-27 BBCH), nustatyta, kad vieną kartą apipurkštų bioorganinių nanotrąšų NAGRO tirpalais runkelių lapu plotas patikimai didesnis 585,51$768,26 \mathrm{~cm}^{2}$ (7,95-10,43 \%), o tirtų trąšu tirpalais cukrinius runkelius apipurškus du kartus, asimiliacinis runkeliu lapų plotas patikimai padidejo 988,82-1 086,45 $\mathrm{cm}^{2}(13,42-14,75 \%)$, palyginti su NAGRO trąšų tirpalais neapipurkštų runkelių lapų plotu.

Cukrinius runkelius apipurškus bioorganinių nanotrąšų NAGRO tirpalais, augalai sukaupe daugiau sausų medžiagų tiek antžeminèje dalyje (lapuose), tiek ir šakniavaisiuose (2 lentelè). Atlikus laboratorines analizes praejjus 14 dienų po apipurškimo tiriamų trąšų tirpalu, sausų medžiagų kiekis runkeliu lapuose patikimai padidejo: apipurškus vieną kartą - 2,20-2,67 g (6,38-7,75 \%), o apipurškus du kartus - 9,47-10,22 g (27,49$29,66 \%$ ), palyginti su sausų medžiagų kiekiu NAGRO trąšų tirpalu neapipurkštų runkelių lapuose. Dèl bioorganinių nanotrąšu NAGRO įtakos ir cukrinių runkelių šakniavaisiuose nustatytas didesnis sausų medžiagų kiekis. Šiomis trąšomis augalus apipurškus vieną kartą, sausų medžiagų kiekis šakniavaisiuose patikimai padidèjo 3,30-4,87 g (15,36-22,67 \%), o NAGRO trąšų tirpalais runkelius apipurškus du kartus, sausų medžiagų kiekis šakniavaisiuose patikimai padidèjo $8,90-10,52 \mathrm{~g}$ (41,43-48,97\%), palyginti su kontroliniuose bandymo laukeliuose augusių cukrinių runkelių šakniavaisiais. Daugiau sausu medžiagų cukriniai runkeliai sukaupė augalus apipurškus 11 ha $^{-1}$ tirtu trąšu tirpalais.

Laboratorines analizes pakartojus po 3 savaičiu runkelių lapų susilietimo eilutèse augimo tarpsniu (26-27 BBCH), taip pat nustatyti didesni sausu 
2 lentelè. Papildomo tręšimo per lapus bioorganinès universalios nanotrąšos NAGRO tirpalais ịtaka cukrinių runkelių lapų plotui ir sausų medžiagų kiekiui

Table 2. Effect of additional leaf spray fertilization with the solutions of bioorganic nano fertilizers NAGRO on the sugar beet leaf area and dry matter content

\begin{tabular}{|c|c|c|c|c|c|c|c|c|c|}
\hline \multirow{3}{*}{$\begin{array}{c}\text { Bandymo variantai } \\
\text { Trial variants }\end{array}$} & \multicolumn{3}{|c|}{$\begin{array}{l}\text { Lapuc plotas } \\
\text { Leaf area }\end{array}$} & \multicolumn{3}{|c|}{$\begin{array}{c}\text { Sausos medžiagos } \\
\text { Dry matter } \\
\text { (antžeminė dalis) } \\
\text { (overground part) }\end{array}$} & \multicolumn{3}{|c|}{$\begin{array}{c}\text { Sausos medžiagos } \\
\text { Dry matter } \\
\text { (šaknys) } \\
\text { (roots) }\end{array}$} \\
\hline & $\mathrm{cm}^{2}$ & \multicolumn{2}{|c|}{$\begin{array}{c}\text { Skirtumas, } \\
\text { palyginti su } \\
\text { netręštais } \\
\text { augalais } \\
\text { Comparison with } \\
\text { non-fertilized } \\
\text { plants } \\
\end{array}$} & $\mathbf{g}$ & \multicolumn{2}{|c|}{$\begin{array}{c}\text { Skirtumas, } \\
\text { palyginti su } \\
\text { netręštais } \\
\text { augalais } \\
\text { Comparison with } \\
\text { non-fertilized } \\
\text { plants } \\
\end{array}$} & $\mathbf{g}$ & \multicolumn{2}{|c|}{$\begin{array}{l}\text { Skirtumas, } \\
\text { palyginti su } \\
\text { netręštais } \\
\text { augalais } \\
\text { Comparison with } \\
\text { non-fertilized } \\
\text { plants }\end{array}$} \\
\hline & & $\mathrm{cm}^{2}$ & $\%$ & & g & $\%$ & & g & $\%$ \\
\hline
\end{tabular}

1. Kontrolinis varian-

tas (foninis NPK tręšimas)
rol (background

3793,86

Control (background

NPK application)

2. Daigai apipurkšti

NAGRO 0,5 L ha ${ }^{-1}$

1 kartą

Single application of

4086,81

292,95

$7,72 \quad 36,65$

2,20

6,38

24,78

3,30

15,36

NAGRO $0.5 \mathrm{l} \mathrm{ha} \mathrm{h}^{-1}$ on the shoots

3. Daigai apipurkšti

NAGRO $1 \mathrm{~L} \mathrm{ha}^{-1}$

1 kartą

Single application of the shoots

\section{Daigai apipurkšti \\ NAGRO 0,5 L ha-1

$$
2 \text { kartus }
$$ \\ Double application of \\ NAGRO $10.5 \mathrm{l} \mathrm{ha}^{-1}$ on the shoots}

\begin{tabular}{|c|c|c|c|c|c|c|c|c|c|}
\hline $\begin{array}{l}\text { 5. Daigai apipurkšti } \\
\text { NAGRO } 1 \mathrm{~L} \mathrm{ha}^{-1} \\
2 \text { kartus } \\
\text { Double application of } \\
\text { NAGRO } 1 \text { l ha }{ }^{-1} \text { on } \\
\text { the shoots }\end{array}$ & 4313,75 & 519,89 & 13,70 & 44,67 & 10,22 & 29,66 & 32,00 & 10,52 & 48,97 \\
\hline $\mathrm{LSD}_{05}$ & 209,23 & & & 2,08 & & & 1,40 & & \\
\hline
\end{tabular}

1. Kontrolinis

variantas (foninis

NPK tręšimas) 
2 lentelè (tęsinys)

Table 2 (continued)

2. Daigai apipurkšti

NAGRO 0,5 $\mathrm{L} \mathrm{ha}^{-1}$

1 kartą

Single application of

$7951,41 \quad 585,51$

7,95

$69,08 \quad 2,78$

4,19

47,34

6,53

16,17

NAGRO $0.5 \mathrm{lha}^{-1}$ on the shoots

\begin{tabular}{|c|c|c|c|c|c|c|c|c|c|}
\hline $\begin{array}{l}\text { 3. Daigai apipurkšti } \\
\text { NAGRO } 1 \mathrm{~L} \mathrm{ha}^{-1} \\
1 \text { kartą } \\
\text { Single application of } \\
\text { NAGRO } 1.0 \text { l ha-1 on } \\
\text { the shoots }\end{array}$ & 8134,16 & 768,26 & 10,43 & 69,76 & 3,46 & 5,22 & 48,87 & 8,12 & 19,93 \\
\hline $\begin{array}{l}\text { 4. Daigai apipurkšti } \\
\text { NAGRO } 0,5 \mathrm{~L} \mathrm{ha}^{-1} \\
2 \text { kartus } \\
\text { Double application of } \\
\text { NAGRO 0.5 l ha-1 on } \\
\text { the shoots }\end{array}$ & 8354,72 & 988,82 & 13,42 & 85,65 & 19,35 & 29,18 & 58,24 & 17,49 & 42,92 \\
\hline $\begin{array}{l}\text { 5. Daigai apipurkšti } \\
\text { NAGRO } 1 \mathrm{~L} \mathrm{ha}{ }^{-1} \\
2 \text { kartus } \\
\text { Double application of } \\
\text { NAGRO } 1 \text { l ha }{ }^{-1} \text { on } \\
\text { the shoots }\end{array}$ & 8452,35 & 1086,45 & 14,75 & 87,53 & 21,23 & 32,02 & 61,51 & 20,76 & 50,94 \\
\hline $\mathrm{LSD}_{05}$ & 404,38 & & & 4,45 & & & 2,70 & & \\
\hline
\end{tabular}

Šaltiniai: ASU Dirvožemio ir pasèlių ekologijos laboratorija, 2012-2013 m. vidutiniai duomenys.

Sources: ASU Soil and Seeding Ecology Experimental Laboratory, mean data for 2012-2013.

medžiagų kiekiai. Augalus bioorganinių nanotrąšų NAGRO tirpalais apipurškus vieną kartą, sausų medžiagų kiekis runkelių lapuose nustatytas 2,78-3,46 g (4,19-5,22 \%), o tiriamų trąšu tirpalais augalus apipurškus du kartus, sausų medžiagų runkelių lapuose nustatyta 19,35-21,23 g $(29,18-32,02 \%)$ patikimai daugiau, palyginti su kontroliniuose bandymo laukeliuose augusiais cukriniais runkeliais (2 lentelè). Dèl bioorganinių nanotrąšų NAGRO ịtakos daugiau sausų medžiagų sukaupe ir cukrinių runkelių šakniavaisiai. Tiriamų trąšų tirpalais apipurškus vieną kartą, runkelių šakniavaisiuose sausų medžiagų kiekis patikimai padidèjo $6,53-8,12 \mathrm{~g}(16,17-19,93 \%)$, o apipurškus du kartus - 17,49-20,76 g (42,9250,94 \%), palyginti su NAGRO trąšomis neapipurkštų cukrinių runkelių šakniavaisiuose nustatytu sausų medžiagų kiekiu. Daugiausia sausų medžiagų cukriniai runkeliai sukaupè augalus apipurškus du kartus $1 \mathrm{~L} \mathrm{ha}^{-1}$ bioorganinių nanotrąšų NAGRO tirpalu.
Cukrinius runkelius apipurškus tiriamų trąšų tirpalais, intensyviau vyko fotosintezès procesai. Bioorganinių nanotrąšu NAGRO 0,5 $\mathrm{L} \mathrm{ha}^{-1}$ ir $1 \mathrm{~L} \mathrm{ha}^{-1}$ tirpalais cukrinius runkelius apipurškus vieną kartą (17-18 $\mathrm{BBCH})$, grynasis fotosintezès produktyvumas padidejo atitinkamai 0,00031 ir $0,00037 \mathrm{~g} \mathrm{~cm}^{2}$ per parą $(1,64-1,96 \%)$, palyginti su kontroliniu bandymų variantu, kur augalai NAGRO trąšomis nebuvo apipurkšti. Tačiau šis padidejjimas nèra esminis (pav.).

Geresni rezultatai gauti tiriamų trąšų tirpalais cukrinius runkelius apipurškus du kartus (17$18 \mathrm{BBCH}$ ir 21-22 BBCH). Taip apipurškus, grynasis fotosintezès produktyvumas patikimai padidejo 0,00354-0,00414 $\mathrm{g} \mathrm{cm}^{2}$ per parą (15,76-18,44\%), palyginti su kontroliniuose bandymo laukeliuose augusių cukrinių runkelių grynuoju fotosintezès produktyvumu.

Bioorganinių universalių nanotrąšų NAGRO $1 \mathrm{~L} \mathrm{ha}^{-1}$ tirpalu apipurškus cukrinius runkelius keturių porų tikrųjų lapelių augimo tarpsniu 


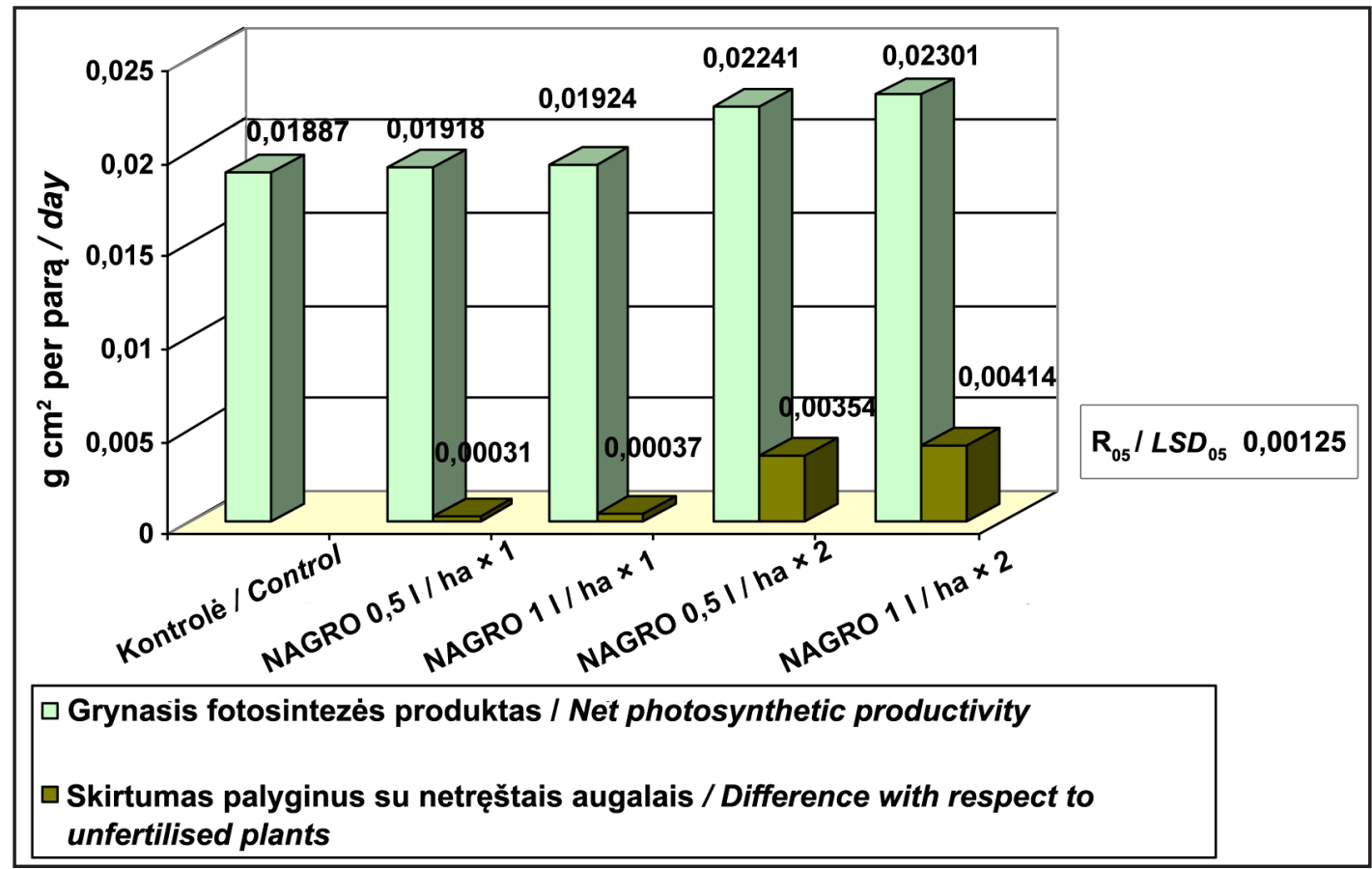

Pav. Papildomo trę̌simo per lapus bioorganinès universalios nanotrąšos NAGRO tirpalais įtaka grynajam fotosintezès produktyvumui

Figure. Effect of additional leaf spray fertilization with bioorganic nano fertilizers NAGRO on the net photosynthesis productivity

Pastaba / Note: Aleksandro Stulginskio universiteto Bandymų stotis, 2012-2013 m. vidutiniai duomenys / ASU Experimental Station, 2012-2013.

(17-18 BBCH), šakniavaisių derlingumas patikimai padidejo $8,13 \mathrm{t} \mathrm{ha}^{-1}(12,6 \%)$, palyginti su kontrole, kur šis biologinis preparatas nebuvo panaudotas (3 lentelè). Cukrinius runkelius bioorganinių universalių nanotrąšų NAGRO tirpalu $1 \mathrm{~L} \mathrm{ha}^{-1}$ apipurškus du kartus (antrą kartą 5-6 porų tikrųjų lapelių augimo tarpsniu, 21$22 \mathrm{BBCH}$ ), šakniavaisių derlingumas statistiškai patikimai padidejo 9,29 $\mathrm{t} \mathrm{ha}^{-1}(14,4 \%)$, palyginti su kontroliniuose laukeliuose augusių cukrinių runkelių derlingumu. Dèl bioorganinių universalių nanotrą̧̨̌ NAGRO įtakos šakniavaisiai užaugo stambesni, vidutinis šakniavaisių svoris derliaus nuemimo metu buvo $112 \mathrm{~g}$ patikimai didesnis, nei kontroliniuose laukeliuose užaugusių šakniavaisių (3 lentelè).

Cukrinius runkelius apipurškus bioorganinių universalių nanotrąšu NAGRO $0,5 \mathrm{~L} \mathrm{ha}^{-1}$ tirpalu vieną kartą, šakniavaisių derlingumas statistiškai patikimai padidejo $3,42 \mathrm{t} \mathrm{ha}^{-1}$ (5,3\%), palyginti su šiuo preparatu neapipurkštų cukrinių runkelių derliumi. Cukrinių runkelių bandymų laukeliuo- se ši preparatą $0,5 \mathrm{~L} \mathrm{ha}^{-1}$ panaudojus du kartus, šakniavaisių prikasta $5,88 \mathrm{t} \mathrm{ha}^{-1}(9,1 \%)$ patikimai daugiau, palyginti su kontrole, kur augalai bioorganinių universalių nanotrąšų NAGRO tirpalais nebuvo apipurkšti. Dẻl bioorganinių universalių nanotrąšų NAGRO įtakos ir mažesnès koncentracijos tirpalais apipurkšti šakniavaisiai užaugo stambesni, svèrè vidutiniškai $30-75 \mathrm{~g}$ patikimai daugiau, nei kontroliniuose laukeliuose augę šakniavaisiai.

Cukrinius runkelius apipurškus bioorganinių trąšų NAGRO tirpalais, šakniavaisiuose nustatyta daugiau cukrinių medžiagų. Šių trąšų $0,5 \mathrm{~L} \mathrm{ha}^{-1}$ tirpalais cukrinius runkelius apipurškus vieną kartą, šakniavaisių cukringumas nustatytas $0,81 \%$ patikimai didesnis, palyginti su bioorganinių universalių nanotrąšų NAGRO tirpalais neapipurkštų šakniavaisių cukringumu. Bioorganinių universalių nanotrąšų NAGRO 0,5 L ha-1 tirpalais cukrinius runkelius apipurškus du kartus, šakniavaisių cukringumas patikimai padidejo 0,99\%, palyginti su kontroliniuose laukeliuose augusių šakniavaisių cukringumu (4 lentelè). 
3 lentelè. Bioorganinių universalių nanotrąšų NAGRO ịtaka cukrinių runkelių derlingumui

Table 3. Effect of bioorganic nano fertilizers NAGRO on the sugar beet productivity

\begin{tabular}{|c|c|c|c|c|c|c|}
\hline $\begin{array}{l}\text { Bandymo variantai } \\
\text { Trial variants }\end{array}$ & 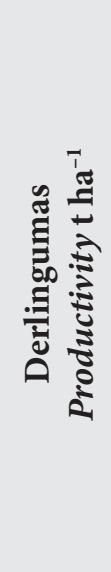 & 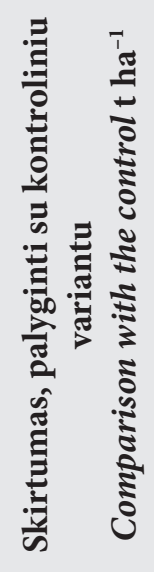 & 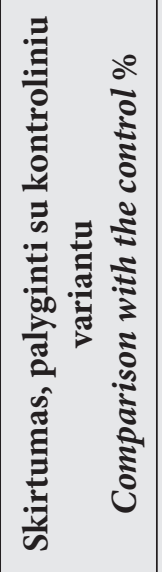 & 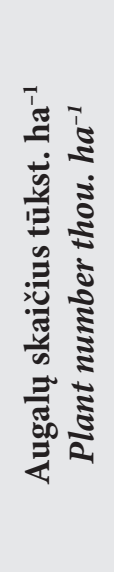 & 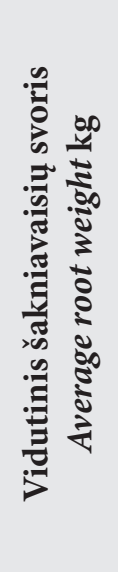 & 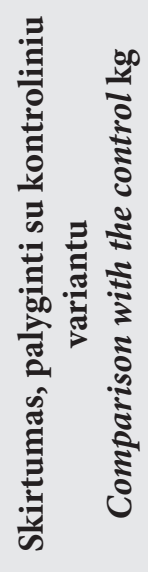 \\
\hline $\begin{array}{l}\text { 1. Kontrolinis variantas } \\
\text { (foninis NPK trę̌simas) } \\
\text { Control (background NPK application) }\end{array}$ & 64,50 & - & - & 84,2 & 0,766 & - \\
\hline 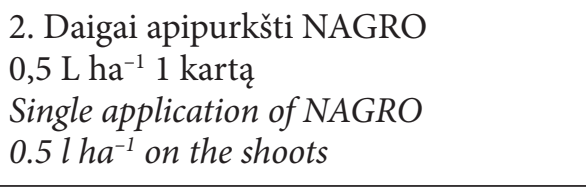 & 67,92 & 3,42 & 5,3 & 85,3 & 0,796 & 0,030 \\
\hline $\begin{array}{l}\text { 3. Daigai apipurkšti NAGRO } \\
1 \mathrm{~L} \mathrm{ha}^{-1} 1 \text { kartą } \\
\text { Single application of NAGRO } \\
1.0 \mathrm{l} \mathrm{ha}^{-1} \text { on the shoots }\end{array}$ & 70,38 & 5,88 & 9,1 & 83,7 & 0,841 & 0,075 \\
\hline $\begin{array}{l}\text { 4. Daigai apipurkšti NAGRO } \\
0,5 \mathrm{~L} \mathrm{ha}^{-1} 2 \text { kartus } \\
\text { Double application of NAGRO } 0.5 \mathrm{lha}^{-1} \\
\text { on the shoots }\end{array}$ & 72,63 & 8,13 & 12,6 & 83,5 & 0,878 & 0,112 \\
\hline $\begin{array}{l}\text { 5. Daigai apipurkšti NAGRO } \\
1 \mathrm{~L} \mathrm{ha}^{-1} 2 \text { kartus } \\
\text { Double application of NAGRO } \\
1 \text { l ha } a^{-1} \text { on the shoots }\end{array}$ & 73,79 & 9,29 & 14,4 & 84,8 & 0,878 & 0,112 \\
\hline $\mathrm{LSD}_{05}$ & 1,803 & & & & 0,0213 & \\
\hline
\end{tabular}

Šaltiniai: Aleksandro Stulginskio universiteto Bandymų stotis, 2012-2013 m.

Sources: ASU Experimental Station, 2012-2013.

Cukrinių runkelių vegetacijos metu bioorganinių universalių nanotrąšų NAGRO $0,5 \mathrm{~L} \mathrm{ha}^{-1}$ tirpalus panaudojus vieną kartą, baltojo cukraus gauta $1,14 \mathrm{t} \mathrm{ha}^{-1}(13,77 \%)$ patikimai daugiau, o šiomis trąšomis $0,5 \mathrm{~L} \mathrm{ha}^{-1}$ runkelius apipurškus du kartus, baltojo cukraus gauta $1,56 \mathrm{t} \mathrm{ha}^{-1}(18,8 \%)$ patikimai daugiau, palyginti su baltojo cukraus kiekiu, gautu iš šiomis bioorganinèmis trąšomis neapipurkštų augalų.

Asimiliatų sintezè ir kaupimas šakniavaisiuose buvo intensyvesni, cukrinius runkelius apipurškus bioorganinių universalių nanotrąšu NAGRO $1 \mathrm{~L} \mathrm{ha}^{-1}$ tirpalais. Dèl šių trąšų poveikio šakniavaisių cukringumas patikimai padidejo: apipurškus vieną kartą - 1,03 \%, apipurškus du kartus - 1,14 \%, palyginti su kontroliniuose laukeliuose užaugusių šakniavaisių cukringumu. Panaudojus bioorganinių universalių nanotrąšu NAGRO $1 \mathrm{~L} \mathrm{ha}^{-1}$ tirpalus, baltojo cukraus gauta atitinkamai 1,61 ir $1,90 \mathrm{t} \mathrm{ha}^{-1}(19,4$ ir 22,9\%) patikimai daugiau, palyginti su kontroliniu variantu, kur šios bioorganinès trą̌sos nebuvo panaudotos. 
4 lentelè. Bioorganinių universalių nanotrąšų NAGRO ịtaka šakniavaisių cukringumui

Table 4. Effect of bioorganic nano fertilizers NAGRO on the sugar content

\begin{tabular}{|c|c|c|c|c|c|}
\hline $\begin{array}{c}\text { Bandymo variantai } \\
\text { Trial variants }\end{array}$ & $\begin{array}{l}\text { Cukringu- } \\
\text { mas } \\
\text { Sugar } \\
\text { content } \\
\%\end{array}$ & $\begin{array}{c}\text { Skirtumas, } \\
\text { palyginti su } \\
\text { kontroliniu } \\
\text { variantu } \\
\text { Comparison } \\
\text { with the control } \\
\%\end{array}$ & $\begin{array}{c}\text { Baltojo } \\
\text { cukraus } \\
\text { kiekis } \\
\text { White sugar } \\
\begin{array}{c}\text { amount } \\
\text { t ha }^{-1}\end{array}\end{array}$ & $\begin{array}{l}\text { Skirtumas, } \\
\text { palyginti su } \\
\text { kontroliniu } \\
\text { variantu } \\
\text { Comparison } \\
\text { with the con- } \\
\text { trol t ha }{ }^{-1}\end{array}$ & $\begin{array}{c}\text { Skirtumas, } \\
\text { palyginti su } \\
\text { kontroliniu } \\
\text { variantu } \\
\text { Comparison } \\
\text { with the } \\
\text { control } \%\end{array}$ \\
\hline $\begin{array}{c}\text { 1. Kontrolinis variantas } \\
\text { (foninis NPK tręšimas) } \\
\text { Control (background NPK ap- } \\
\text { plication) }\end{array}$ & 16,65 & - & 8,28 & - & - \\
\hline $\begin{array}{l}\text { 2. Daigai apipurkšti NAGRO } \\
0,5 \mathrm{~L} \mathrm{ha}^{-1} 1 \text { kartą } \\
\text { Single application of NAGRO } \\
0.5 \mathrm{l} \mathrm{ha}^{-1} \text { on the shoots }\end{array}$ & 17,46 & 0,81 & 9,42 & 1,14 & 13,7 \\
\hline $\begin{array}{l}\text { 3. Daigai apipurkšti NAGRO } \\
1 \mathrm{~L} \mathrm{ha}^{-1} 1 \text { kartą } \\
\text { Single application of NAGRO } \\
1.0 \mathrm{l} \mathrm{ha}^{-1} \text { on the shoots }\end{array}$ & 17,64 & 0,99 & 9,84 & 1,56 & 18,8 \\
\hline $\begin{array}{l}\text { 4. Daigai apipurkšti NAGRO } \\
0,5 \mathrm{~L} \mathrm{ha}^{-1} 2 \text { kartus } \\
\text { Double application of NAGRO } \\
0.5 \mathrm{l} \mathrm{ha}^{-1} \text { on the shoots }\end{array}$ & 17,68 & 1,03 & 9,89 & 1,61 & 19,4 \\
\hline $\begin{array}{l}\text { 5. Daigai apipurkšti NAGRO } \\
1 \mathrm{~L} \mathrm{ha}^{-1} 2 \text { kartus } \\
\text { Double application of NAGRO } \\
1 \mathrm{l} \mathrm{ha}^{-1} \text { on the shoots }\end{array}$ & 17,79 & 1,14 & 10,18 & 1,90 & 22,9 \\
\hline $\mathrm{LSD}_{05}$ & 0,446 & & 0,234 & & \\
\hline
\end{tabular}

Šaltiniai: Aleksandro Stulginskio universiteto Bandymų stotis, 2012-2013 m.

Sources: ASU Experimental Station, 2012-2013.

\section{IŠVADOS}

1. Cukrinius runkelius $17-18 \mathrm{BBCH}$ augimo tarpsniu apipurškus bioorganinių nanotrąšuc NAGRO $1 \mathrm{~L} \mathrm{ha}^{-1}$ tirpalu, runkeliai intensyviau augo: apipurškus vieną kartą - lapų skaičius 23-24 BBCH tarpsniu padidejo vidutiniškai 3,7 (18,7\%), lapų plotas - 9,15\%, šakniavaisių diametras $-1,1 \mathrm{~cm}(11,9 \%)$, vidutinè augalo biomasè - 69,8 g (10,4\%); cukrinius runkelius šių trąšų tirpalu apipurškus du kartus (17-18 ir 21-22 $\mathrm{BBCH}$ augimo tarpsniai) lapų skaičius patikimai padidejjo 4,6 vnt. (23,2\%), lapų plotas - 13,70 \%, šakniavaisių diametras - 1,5 cm (16,3\%), vidutinè augalo biomase $-86,2 \mathrm{~g}(12,8 \%)$, palyginti su kontroliniuose bandymo laukeliuose augusiais cukriniais runkeliais.

2. Biometrinius matavimus pakartojus $26-27$ $\mathrm{BBCH}$ augimo tarpsniu, nustatyta, kad bioorganinių nanotrąšų NAGRO $1 \mathrm{~L} \mathrm{ha}^{-1}$ tirpalu vieną kartą apipurkšti cukriniai runkeliai išaugino 4,8 vnt. (17,4 \%) lapų patikimai daugiau, lapų plotas padidejjo $10,43 \%$, vidutinis šakniavaisių diametras - $1,4 \mathrm{~cm}(11,9 \%)$, vidutinè augalo biomasè - 290,4 g (25,5 \%) esmingai didesné, palyginti su šių trąšų tirpalu neapipurkštais augalais. Cukrinius runkelius tiriamų trą̌su $1 \mathrm{~L} \mathrm{ha}^{-1}$ tirpalu apipurškus du kartus, runkeliai išaugino 7,6 vnt. (27,6 \%) daugiau lapų, jų plotas padidejo $14,75 \%$, vidutinis šakniavaisių diametras nustatytas $1,9 \mathrm{~cm}(16,2 \%)$ 
didesnis, o vidutinè augalo biomasė buvo 476,3 g (41,6 \%) didesnè, palyginti su kontroliniuose bandymo laukeliuose augusiais cukriniais runkeliais.

3. Dèl bioorganinių nanotrąšų NAGRO ịtakos intensyviau vyko sausų medžiagų sintezès ir kaupimo procesai. Cukrinius runkelius vieną kartą apipurškus tiriamų trąšų $1 \mathrm{~L} \mathrm{ha}^{-1}$ tirpalu, sausų medžiagų runkelių lapuose nustatyta $7,75 \%$, šakniavaisiuose $-22,67 \%$ patikimai daugiau, o apipurškus du kartus, sausų medžiagų lapuose nustatyta 29,66 \%, šakniavaisiuose - 48,97 \% patikimai daugiau, palyginti su kontroliniuose bandymo laukeliuose augusiais cukriniais runkeliais. Laboratorines analizes pakartojus runkeliams esant $26-27 \mathrm{BBCH}$ augimo tarpsnyje, sausų medžiagų lapuose nustatyta 5,22 \%, šakniavaisiuose - 19,93\% patikimai daugiau, palyginti su kontroliniu bandymo variantu. Tiriamų bioorganinių trąšų $1 \mathrm{~L} \mathrm{ha}^{-1}$ tirpalu cukrinius runkelius apipurškus du kartus, sausų medžiagų runkelių lapuose nustatyta 32,02 \%, šakniavaisiuose - 50,94 \% patikimai daugiau, palyginti su kontroliniuose bandymo laukeliuose augusiais cukriniais runkeliais.

4. Dèl bioorganinių nanotrąšu NAGRO įtakos intensyviau vyko fotosintezès procesai. Cukrinius runkelius tiriamų trąšų $1 \mathrm{~L} \mathrm{ha}^{-1}$ tirpalu apipurškus vieną kartą, grynosios fotosintezès produktyvumas padidejo $1,96 \%$, tačiau šis padidejjimas nèra esminis. Statistikai patikimai grynasis fotosintezès produktyvumas padidejo cukrinius runkelius tiriamų bioorganinių trąšų tirpalais apipurškus du kartus. Panaudojus $0,5 \mathrm{~L} \mathrm{ha}^{-1}$ tirpalą, grynasis fotosintezès produktyvumas padidèjo $15,76 \%$, o panaudojus $1 \mathrm{l} \mathrm{ha}^{-1}$ trąšų tirpalą - 18,44\%, palyginti su NAGRO trąšomis neapipurkštų augalų grynuoju fotosintezès produktyvumu.

5. Cukrinių runkelių daigus apipurškus bioorganinių universalių nanotrąšų NAGRO $1 \mathrm{~L} \mathrm{ha}^{-1}$ tirpalu, šakniavaisių derlingumas patikimai padidejo 8,13-9,29 $\mathrm{t} \mathrm{ha}^{-1}(12,6-14,4 \%)$, palyginti su kontroliniuose bandymų laukeliuose augusių runkelių derlingumu, kur NAGRO trąšos nebuvo naudotos. Cukrinių runkelių daigus apipurškus bioorganinių universalių nanotrąšu NAGRO $0,5 \mathrm{~L} \mathrm{ha}^{-1}$ tirpalu, šakniavaisių derlingumas patikimai padidejo $3,42-5,88 \mathrm{t} \mathrm{ha}^{-1}(5,3-9,1 \%)$, palyginti su kontrole, kur šis preparatas nebuvo naudotas.

6. Cukrinès medžiagos šakniavaisiuose intensyviau buvo kaupiamos panaudojus bioorganinių universalių nanotrąšu NAGRO $1 \mathrm{~L} \mathrm{ha}^{-1}$ tirpalus.
Šakniavaisių cukringumas dèl šių trąšų poveikio patikimai padidejo $1,03-1,14 \%$, baltojo cukraus gauta 1,61 ir 1,90 t ha $^{-1}(19,4$ ir 22,9\%) daugiau, nei iš cukrinių runkelių, augusių kontroliniuose bandymų laukeliuose. Cukrinius runkelius apipurškus bioorganinių universalių nanotrąšų NAGRO $0,5 \mathrm{~L} \mathrm{ha}^{-1}$ tirpalais, šakniavaisių cukringumas patikimai padidejo $0,81-0,99 \%$, baltojo cukraus gauta 1,14-1,56 t ha ${ }^{-1}(13,7-18,8 \%)$ daugiau, palyginti su kontrole, kur šis preparatas nebuvo naudotas.

Gauta 20140506 Priima 20140626

\section{LITERATŪRA}

1. Deveikyte I. 2000. Biological Effectiveness of the Mixture of Herbicides for Sugar Beet. Development of Environmentally Friendly Plant Protection in the Baltic Region: Proceeding of International Conference. Tartu. P. 28-30.

2. Deveikytė I., Petkevičienè B., Kaunas J. 2009. Cukriniai runkeliai. Agrobiologija, tyrimai, technologijos. Akademija, Kèdainių r. P. 65-97.

3. Jakienė E., Venskutonis V. 2008. Augimo reguliatoriai augalininkystëje. Akademija. $80 \mathrm{p}$.

4. Jakiene E. 2013. The effect of the microelement fertilizers and biological preparation Terra Sorb Foliar on spring rape crop. Žemés ūkio mokslai. T. 20. Nr. 2. P. $75-83$.

5. Mažvila J., Staugaitis G., Arbačiauskas J., Vaišvila Z., Šumskis D. 2008. Lietuvos dirvožemių agrocheminès savybès ir jų kaita po nepriklausomybès atkūrimo. Žemés ūkio mokslai. T. 15. Nr. 3. P. 13-21.

6. Mažvila J., Vaičys M., Buivydaitè V. 2003. Naujausi Lietuvos dirvožemių genetiniai tyrimai klasifikacijai tobulinti. Žemés ükio mokslai. Nr. 4. P. 19-31.

7. Mickevičius V., Voskienė A., Jonuškienè I., Kolosej R., Šiugždaitė J., Venskutonis P. R., Kazernavičiūtė R., Brazienè Z., Jakienè E. 2013. Synthesis and biological activity of 3-[phenyl(1,3-thiazol-2-yl)-amino]propanoic acids and their derivatives. Molecules. Vol. 18. No. 12. P. $15000-15018$.

8. Narkevičius G., Šiuliauskas A., Liakas V., Romaneckas K. 2004. Šiuolaikinès augalininkystes technologijos. Akademija. $159 \mathrm{p}$.

9. Pidgeon J. D., Ober E. S., Qi A. 2006. Using multienvironment sugar beet variety trials to screen for drought tolerance. Field Crops Research. Vol. 95. Issues 2-3. P. 268-279.

10. Pranckietienè I., Šidlauskas G., Tripolskaja L., Dromantienė R. 2008. Skystujų azoto trąšų su aminorūgščių priedais efektyvumas žieminiams kviečiams ir vasariniams rapsams. Naujausi agronomijos tyrimu rezultatai: konferencijos pranešimai. Nr. 40. P. 57-63. 
11. Romaneckas K., Romaneckienè R. 2009. Lapų trąšu poveikis cukrinių runkelių derliui ir kokybei. Vagos: mokslo darbai. Nr. 82(35). P. 41-47.

12. Shpaar D. 2006. Sakharnaya svyokla. DLV Agrodelo. P. 315.

13. Suojala T. 2000. Growth of and partitioning between shoot and storage root of carrot in northern climate. Agricultural and Food Science in Finland. Vol. 9. No. 1. P. 49-59.

14. Šiuliauskas A., Liakas V., Paltanavičius V., Rauckis V. 2008. Azoto trąšu normų įtakos cukrinių runkelių derliaus formavimuisi tyrimai mažo humusingumo dirvožemyje. Vagos: mokslo darbai. Nr. 78(31). P. 37-42.

15. Šiuliauskas A., Liakas V. 2012. Inovatyvios cukrinių runkelių auginimo technologijos (žiūrèta 201402 10). Prieiga per internetą: http: // www. Kustodija.lt / index. Php/lt/info/55

16. Šlapakauskas V., Duchovskis P. 2008. Augalu produktyvumas. Klaipeda. P. 52-54.

17. Tarakanovas P., Raudonius S. 2003. Agronominiu tyrimu duomenu statistine analizé taikant kompiuterines programas ANOVA, STAT, SPLIT-PLOT iš paketo SELEKCIJA ir IRRISTAT. Akademija. $56 \mathrm{p}$.
Elena Jakienè

\section{EFFECT OF THE BIOORGANIC FERTILIZERS ON SUGAR BEET PRODUCTIVITY INCREASE}

Sum mary

The trials were carried out at the Aleksandras Stulginskis University Experimental Station over the period 20122013. The focus of the study was on the effect of additional leaf spray fertilization application of nano fertilizers NAGRO on Ernestina variety cugar beet (Beta vulgaris L., var. saccharifera) growth, photosynthesis indices, root productivity and quality. The trial field was treated with NPK 8:20:30 $300 \mathrm{~kg} \mathrm{ha}^{-1}+$ amonium salphetre $\left(\mathrm{N}_{34}\right) 130 \mathrm{~kg} \mathrm{ha}^{-1}$ (background treatment of the considered trial - control). Solutions of the bioenergetic universal nano fertilizers NAGRO 0.5 and $11 \mathrm{ha}^{-1}$ were applied on sugar beet sprouts at the four leaves stage (17-18 BBCH). Sugar beetroots were treated with the bioorganic fertilizer solutions at the stage of 5-6 true leaves (21-22 BBCH). Other agrotechnical measures were applied according to the sugar beet growing technology used on the Experimental Station. Sugar beetroots were harvested on the third of October. Sugar content in the roots was established at the Marijampole Sugar Refinery.

The obtained results revealed that double application of the bioorganic fertilizer NAGRO $11 \mathrm{ha}^{-1}$ solution resulted in a better sugar beetroot growth and higher productivity. Consistently, the accumulation of the dry matter was found to be more intensive, and the net productivity of photosynthesis increased by $18.4 \%$. The comparison with the control revealed that double application of the solution of bioorganic nano fertilizers NAGRO $11 \mathrm{ha}^{-1}$ resulted in significantly higher root productivity by $9.29 \mathrm{t}$ ha, higher sugar content by $1.14 \%$, higher white sugar content by $1.90 \mathrm{tha}^{-1}(22.9 \%)$.

Key words: sugar beetroots, bioorganic fertilizers, photosynthetic indices, productivity, sugar content 